Acta Technologica Agriculturae 4

Nitra, Slovaca Universitas Agriculturae Nitriae, 2015, pp. 113-117

\title{
INFLUENCE OF MACHINE EXPLOITATION EFFECTIVENESS ON FURNITURE PRODUCTION QUALITY LEVEL
}

\author{
Renata STASIAK-BETLEJEWSKA ${ }^{1 *}$, Miroslav PRÍSTAVKA² ${ }^{2}$ Agnieszka CZAJKOWSKA ${ }^{3}$, Marián TÓTH² \\ ${ }^{1 *}$ Czestochowa University of Technology, Poland \\ ${ }^{2}$ Slovak University of Agriculture in Nitra, Slovak Republic \\ ${ }^{3}$ Kielce University of Technology, Poland
}

One of the most important factors determining the company's capacity to produce high quality products is the level of machinery operation effectiveness. Companies having modern machinery are characterized by high productivity. To obtain a high quality product, the equipment should be properly used, without any failure, which contributes significantly to the exploitation level increase. The modernity level and the exploitation effectiveness level for chosen machine producing furniture components in relation to the product quality level were analysed in the paper. As a result of the research findings analysis, proposals for corrective actions with regard to machinery maintenance and production processes were presented.

Keywords: quality; machine exploitation; production; furniture; PAMCO

Currently, the main objective of the exploitation science is seeking the operational reliability growth in terms of technical facilities, safety and quality to extend the life of facilities, the increase in its productivity and care for the environment (Jelačič et al., 2010). Exploitation means the use and operation of a single device (machine or group of machines). Therefore, this term includes organizational, technical, economic and social issues concerning the interaction of man and machine. The basic process in the machines exploitation system is the use of machines and devices. Its effectiveness depends primarily on the rational use of machines, its technical characteristics, economical use, process organization and its work performance (Lančarič and Savov, 2012). Technical characteristics of the machine include functionality (the ability to fulfil the assumed function), efficiency (work performance, productivity), flexibility (the ability to carry out many functions), the degree of readiness (durability and reliability) and the quality of use (Borkowski et al., 2006).

The method of supplying parts and assemblies and service and repair activities determine the proper handling process. Operating rules are developed based on scientific research. Modern research consumables relate, inter alia, to:

- characterization, modelling and improvement of facilities and operating systems;

- reconstruction and redevelopment strategies for operating systems (restructuring of resource capacity and maintenance);

- prediction of durability and reliability;

- ensuring the proper maintenance, overhaul, repair, regeneration and supplies;

- economics of operation and service.
In addition to solving technical issues, organizational and economic, scientific activity also relates to the operational and environmental education and research related to the improvement of relations associated with operation (Legutko, 2004).

The use of machines and devices is defined as the exploitation of a technical object for its intended purpose and functional properties. Handling is defined as the maintenance of the object and its restoration to required functional properties by reviewing, regulation, maintenance and repairs. Power supply is delivered to building materials (by weight) of energy and, in particular, with regard to numerical control devices and information. Planning and decision-making processes, reporting and analysis are identified as the management process (Kaźmierczak, 2000).

\section{Material and methods}

The research analysis is based on research findings from a medium-sized manufacturing company that is a producer of furniture, including interior design. It is situated in Silesia in Poland. The last two decades the company has acquired extensive experience in the production of furniture. The company employs 23 workers (Korenko and Kaplík, 2011). To meet customer expectations, the owner of the company has equipped the manufacturing plant with modern machinery that allows for the production of high quality furniture. At the same time, the advanced technology that allows for attractive design and high quality production was implemented (Korenko et al., 2010). 


\section{Assessment of machine modernity level based on $A B C$ method}

One of the methods used to assess the machines and devices modernity level is an $A B C$ method ( $A B C$ analysis). It is based on the modernity categorization of components' parts in the machine or device. Basic subassembly corresponds to the category $A$, which includes the fundamental parts of machinery to ensure the product special attributes. The category $B$ is defined as supporting components. Ancillary components of the category $C$ are mainly technologies that are not subject to innovative activity and do not have more important meaning when buying a new machine (Hrubec and Borkowski, 2006).

The ABC analysis applies the technology used to manufacture various components used in the machine and assessing their modernity in a five-point Parker's scale. This scale consists of the following levels (Borkowski et al., 2006):

level 1 - including straight parts that are possible to be manufactured by using craft techniques, e.g. the foundation of the machine;

level 2 - including parts manufactured by using the technologies well known for many years, e.g. the standard engine cooling system;

level 3 - including parts produced by using the technology requiring technical expertise, e.g. a standard electric motor;

level 4 - including parts prepared by using modern market technologies, e.g. diagnosis display on the computer control panel;

level 5 - including parts being a result of combined application of advanced production technology, patented and occurring only in the machine specific company.

The research object analysed by using the $A B C$ method is a panel saw GIBEN SMART SP 80. The analysed panel saw is a machine for cutting one line (Kotorová and Korenko, 2012). It combines all advantages of the machines produced by the Giben company that ensure compliance with the requirements of customers. The saw is very efficient and precise and it is reliable during long periods of use. The research results are presented in Table 1.

Table 1 Assessment of the machine components modernity level for the panel saw GIBEN SMART SP 80

\begin{tabular}{|c|c|c|c|}
\hline Sub-assembly & Subcategories & $\begin{array}{c}\text { Component/element } \\
\text { of the machine }\end{array}$ & $\begin{array}{c}\text { Modernity } \\
\text { level }\end{array}$ \\
\hline \multirow{4}{*}{ A } & $\mathrm{A} 1$ & control system & 4 \\
\hline & $\mathrm{A} 2$ & control panel & 4 \\
\hline & A3 & main saw & 5 \\
\hline & A4 & undercutting saw & 5 \\
\hline \multirow{5}{*}{ B } & B1 & main saw drive motor & 4 \\
\hline & B2 & scoring blade drive motor & 4 \\
\hline & B3 & carriage drive motor & 4 \\
\hline & B4 & power supply system & 3 \\
\hline & B5 & pressure beam & 4 \\
\hline \multirow{8}{*}{$\mathbf{C}$} & $\mathrm{C} 1$ & design of the machine (cover) & 4 \\
\hline & $\mathrm{C} 2$ & roller supports & 4 \\
\hline & $\mathrm{C} 3$ & grapples & 3 \\
\hline & $\mathrm{C} 4$ & followers & 4 \\
\hline & $\mathrm{C} 5$ & operating forklift & 4 \\
\hline & C6 & base lath & 4 \\
\hline & $C 7$ & covers & 3 \\
\hline & $\mathrm{C} 8$ & panels & 4 \\
\hline
\end{tabular}

The components contained in the category A were classified at a high modernity level, which amounted to an average over 4 . The components contained in the category $B$ and $C$ were classified into the fourth level according to Parker's scale. The graphical presentation of research findings analysis is shown in Figure 1.

The parts included in individual components, as shown in Table 1 and Figure 1, can be classified according to Parker's scale as follows:

- A in 50\% amounted to the fourth modernity level and in $50 \%$ to the fifth modernity level;

- B in 75\% at the fourth modernity level and in $25 \%$ at the third modernity level;

- C in 75\% at the fourth modernity level and in $25 \%$ at the third modernity level.

It was stated that 12 components of the analysed machine were included in the fourth modernity level according to Parker's scale, which allows for producing high quality products.

\section{PAMCO indicators applying to machines exploitation} effectiveness in furniture industry

The PAMCO method is used to measure the machines efficiency and it is based on the group of indicators defined based on time structure. The assessment of material resources use (Plant \& Machine Control PAMCO) was applied in 1976 as a common language defining the companies and the machines efficiency that allow applying the same criteria for comparing companies with similar profiles and similar manufacturing machine fleet (Savov and Lančarič, 2013). In 1990 PAMCO definitions were simplified and standardised for all companies so that the results give a simple and fast way to compare. PAMCO shows the parameters of work measurement and reporting of technical objects operation. It defines also the working time of the machine in order to analyse the machines and processes operation to reduce the number of parameters used so far (Kadnár et al., 2014). It is the basis for measuring these devices, which can be modified. Time, according to the PAMCO method, has been divided into types that are a base for indictors giving a full and clear picture of machine use 


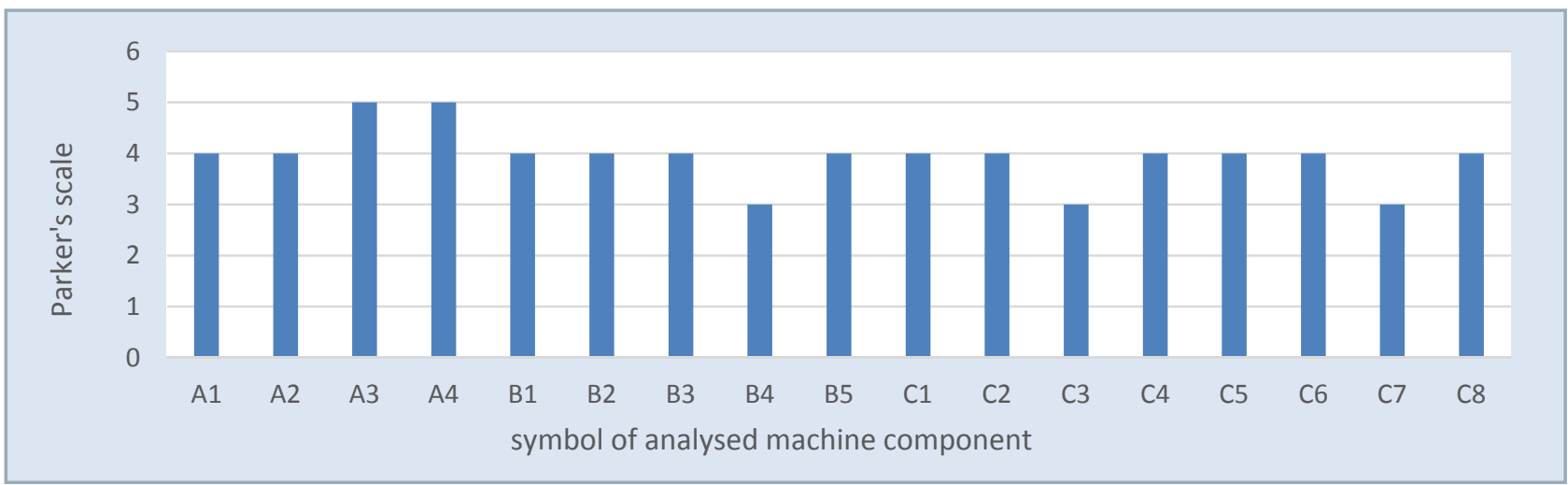

Figure 1 Graphical presentation of machine components' modernity level for the panel Saw GIBEN SMART SP 80 Source: own study

and factory productivity. The types and structure of PAMCO times were presented in Table 2, which includes research findings (Oblak and Jošt, 2011).

There are some coefficients calculated with the PAMCO method (Borkowski et al., 2006):

where:

OT - operation time

$A T$ - available time

Asset availability $(A A)$ :

Production efficiency (PE):

$$
P E=\frac{E T}{P T} \times 100, \%
$$

$$
A A=\frac{A T}{T T} \times 100, \%
$$

where:

AT - available time

TT - total time

where:
$E T$ - effective time

$P T$ - production time

\section{Asset utilisation (AUt):}

$$
A U t=\frac{U T}{T T} \times 100, \%
$$

$$
O E=\frac{E T}{O T} \times 100, \%
$$

where:

$E T$ - effective time

OT - operation time

Available utilisation $(A U)$ :

$$
A U=\frac{O T}{A T} \times 100, \%
$$

(3) where:

OT - operation time

TT - total time

UT - used time

$T T$ - total time

\begin{tabular}{|c|c|c|c|c|c|c|c|c|c|c|}
\hline 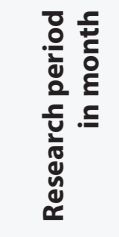 & 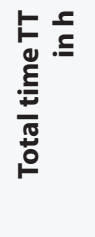 & 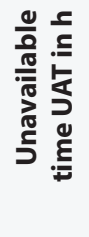 & 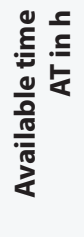 & 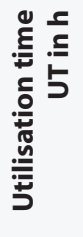 & 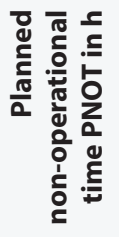 & 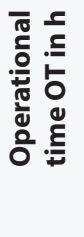 & 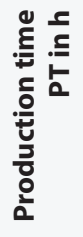 & 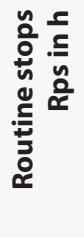 & 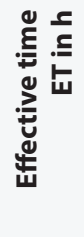 & 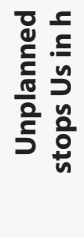 \\
\hline 1 & 240 & 80 & 160 & 124 & 5 & 119 & 114 & 5 & 102 & 12 \\
\hline 2 & 240 & 80 & 160 & 130 & 3 & 127 & 125 & 2 & 111 & 14 \\
\hline 3 & 240 & 80 & 160 & 128 & 2 & 126 & 121 & 5 & 111 & 10 \\
\hline 4 & 240 & 80 & 160 & 122 & 1 & 121 & 118 & 3 & 107 & 11 \\
\hline 5 & 240 & 80 & 160 & 132 & 2 & 130 & 126 & 4 & 119 & 7 \\
\hline 6 & 240 & 80 & 160 & 130 & 2 & 128 & 124 & 4 & 110 & 14 \\
\hline
\end{tabular}

\section{Operational utilisation (OU):}

$$
O U=\frac{O T}{T T} \times 100, \%
$$

Table 2 Operation time value coefficients analysis for panel saw GIBEN SMART SP 80 for research period 6 months. 


\section{Production utilisation $(P U)$ :}

$$
P U=\frac{P T}{T T} \times 100, \%
$$

where:

PT - production time

TT - total time

\section{Effective utilisation (EU):}

$$
E U=\frac{E T}{T T} \times 100, \%
$$

where:

$E T$ - effective time
$T T$ - total time

\section{Results and discussion}

On the basis of those indicators, the company can be settled on the work performance in the field of manufacturing, and the results can be compared with other companies. Results constitute the basis for the decision process in terms of company development plans. Optimal values of PAMCO coefficients should reach the following values:

- production efficiency (PE): should be as high as possible and should not exceed a value of about $95 \%$;

- operational efficiency (OE): 92.5\%;

- available utilisation time $(A U)$ : should be approximately $90 \%$;

- asset availability $(A A)$ : should be approximately $97 \%$;

- asset utilisation $(A U t)$ : it is required to accept a value of $65 \%$;

- operational utilisation $(O U)$ : should be approximately $62 \%$;

- production utilisation $(P U)$ : optimum value should be less than $60 \%$;

- effective utilisation $(E U)$ : its value should be at the level of $50 \%$.

The PAMCO analysis carried out for the panel saw GIBEN SMART SP 80

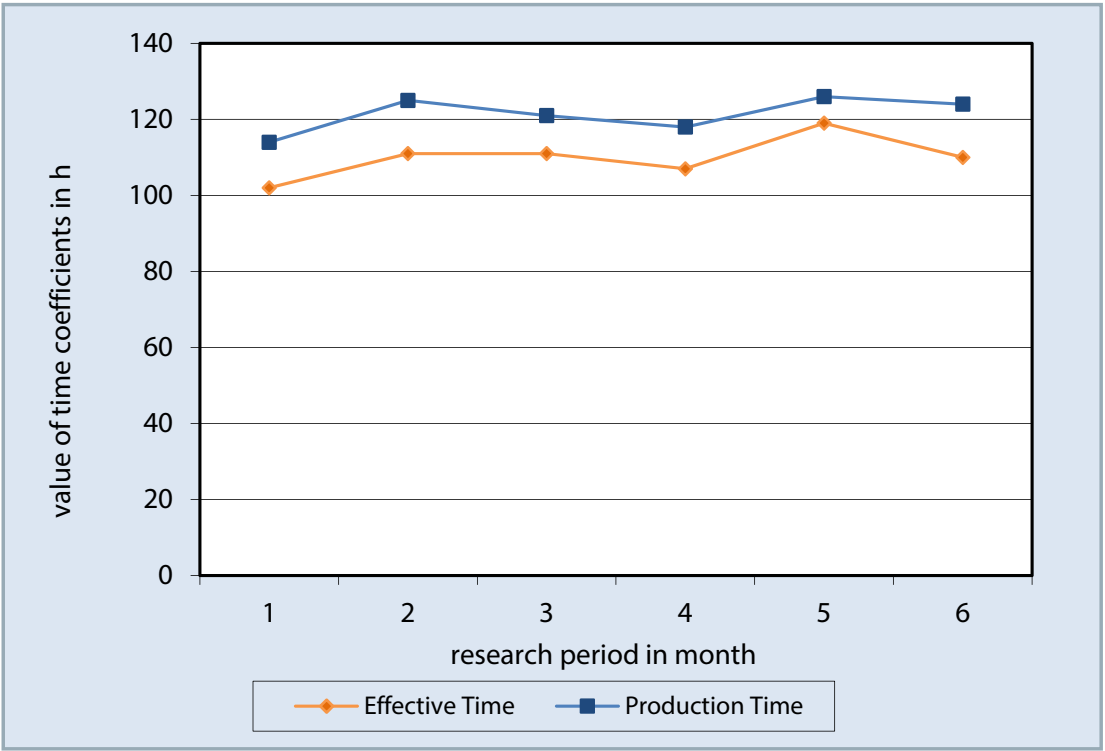

Figure 2 Graphical presentation of chosen operation time values for the panel saw GIBEN SMART SP 80

Source: own study

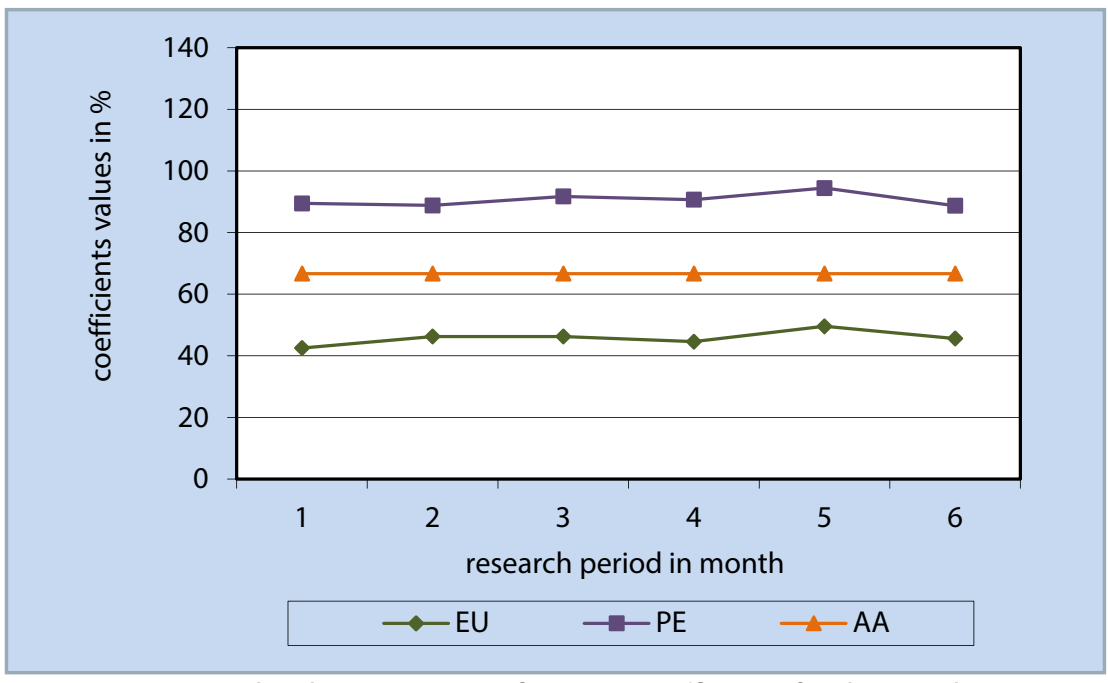

Figure 3 Graphical presentation of PAMCO coefficients for the panel saw GIBEN SMART SP 80

Source: own study

has been made in the research study period of July - December 2014. The results of the panel saw operation time analysis for six months with
PAMCO coefficients are shown in Table 2.

The values of operation times are presented graphically in Figure 2.

Table 3 PAMCO coefficients analysis for the panel saw GIBEN SMART SP 80 for the research period of six months

\begin{tabular}{|l||c|c|c|c|c|c|c|c|}
\hline Research period in month & $P E$ in \% & OE in \% & $A U$ in \% & $A A$ in \% & $A U t$ in \% & OU in \% & $P U$ in \% & $E U$ in \% \\
\hline \hline $\mathbf{1}$ & 89.47 & 85.71 & 74.37 & 66.67 & 51.67 & 49.58 & 47.5 & 42.5 \\
\hline $\mathbf{2}$ & 88.8 & 87.4 & 79.37 & 66.67 & 54.17 & 52.92 & 52.08 & 46.25 \\
\hline $\mathbf{3}$ & 91.73 & 88.09 & 78.75 & 66.67 & 53.33 & 52.5 & 50.42 & 46.25 \\
\hline $\mathbf{4}$ & 90.68 & 88.43 & 75.62 & 66.67 & 50.83 & 50.42 & 49.17 & 44.59 \\
\hline $\mathbf{5}$ & 94.44 & 91.54 & 81.25 & 66.67 & 55 & 54.17 & 52.5 & 49.58 \\
\hline $\mathbf{6}$ & 88.71 & 85.94 & 80 & 66.67 & 54.17 & 53.33 & 51.67 & 45.83 \\
\hline
\end{tabular}

Source: own study 
Based on the data shown in Figure 2, it can be stated that the value of the effective time of machine work in the same period is less than production time. The times shown in Table 3 were calculated on the basis of PAMCO coefficients described below.

The coefficients included in Table 3 were presented graphically using linear charts for the coefficients $E U, P E$, and $A A$.

The analysis of operation time for the panel saw GIBEN SMART SP 80 shows that the lowest value of effective time (ET) amounted to $102 \mathrm{~h}$ in the first research month. As a result of research using the PAMCO analysis, it has, however, been shown that the actual utilisation coefficient of total working time $(E U)$ reached the lowest value. Based on these results, it was found that all PAMCO coefficients reached values lower than optimal, which indicates that the equipment is not fully utilised, and thus its efficiency is not high. The manager in this case should better plan the machine operation schedule.

The next step in the machine operation analysis is the quality level analysis of process results based on the identification of non-conformities found in product quality control documents. Non-conformities identified during the production of the finished product were largely caused by the analysed machine (panel saw). There were identified jagged edges, material cracks and an inadequate size of material. As the first reason for non-conformity, an incorrect operation of the machine by the operator in connection with improperly chosen saw blade was proved. Cracks in material during processing were caused by improper handling saws as well as the quality of purchased material. Inadequate measures were the result of saw work precision as well as incorrect measurements performed by employees.

\section{Conclusion}

As the final result of the machine modernity level analysis and PAMCO coefficients analysis, it was stated that there is a need to formulate corrective actions in terms of analysed machine exploitation. Crucial proposal concerns production process improvement within shortening production equipment changeovers by using a single-minute exchange of die (SMED) method. In order to improve the production in the analysed company, training for production workers within the short setup equipment should be carried out. Another element of improvement should concern the implementation of a preparatory stage determining the current work organisation at the production department.
Subsequently, it is necessary to identify and distinguish between internal and external changeover and to prepare for the transport of tools and equipment during the machine operation.

\section{Acknowledgement}

This paper was prepared with a financial support of the grant project KEGA no. 035SPU-4/2014 'Integrating innovative trends in metal working, metrology and quality management in university study'.

\section{References}

BORKOWSKI, S. - SELEJDAK, J. - SALAMON, SZ. 2006. Efektywność eksploatacji maszyn i urządzeń. Częstochowa : Wydawnictwo Politechniki Częstochowskiej.

HRUBEC, J. - BORKOWSKI, S. 2006. Efektywność eksploatacji maszyn i zdolność jakościowa procesu. Warszawa : Wydawnictwo Orgmasz. JELAČIĆ, D. - GRLADINOVIĆ, T. - PIRC, A. - OBLAK, L. 2010. Motivation factors analysis in industrial plants. In Strojarstvo, vol. 52, no. 3, pp. 349-361.

KADNÁR, M. - RUSNÁK, J. - BUJNA, M. - VALÍČEK, J. - KUŠNEROVÁ, M. - TÖKÖLY, P. 2014. Research of journal bearings for using in agricultural mobile machines. In Research in Agricultural Engineering, vol. 60, special iss. (2014), pp. 25-30.

KAŹMIERCZAK, J. 2000. Eksploatacja systemów technicznych. Gliwice : Wydawnictwo politechniki Śląskiej.

KORENKO, M. - KAPLÍK, P. 2011. Improvement of process performance and efficiency in a production organisation using a Six Sigma method. In Acta Technologica Agriculturae, vol. 14, no. 4.

KORENKO, M. - KAPLÍK, P. - BULGAKOV, V. 2010. Implementation of $5 \mathrm{~S}$ approach in the manufacturing organization. In Naukovij Visnik Nacionalnogo Universitetu Bioresursiv i Prirodokoristuvanja Ukrajiny, vol. 144, no. 5.

KOTOROVÁ, M. - KORENKO, M. 2012. Využitie štatistických metód v organizácii. In Technika v technológiách agrosektora 2012 : Collection of scientific papers. Nitra : SUA, pp. 93-97.

LANČARIČ, D. - SAVOV, R. 2012. The main elements of diversity in the Slovak Republic. In Diveristy Management. Plzeň : NAVA, pp. 26-34.

LEGUTKO, S. 2004. Podstawy eksploatacji maszyn i urządzeń. Warszawa : Wydawnictwo Szkolne i Pedagogiczne Spółka Akcyjna. OBLAK, L. - JOŠT, M. 2011. Methodology for studying the ecological quality of furniture. In Drvna Industrija, vol. 62, no. 3, pp. 171-176. SAVOV, R. - LANČARIČ, D. 2013. Manažment podniku. Nitra : SUA. 